\title{
Variantes Lexicais para Alpargatas no Paraná e na Região Nordeste do Brasil: um estudo etnolinguístico
}

Les Variantes Lexicales pour le Mot Espadrilles au Paraná ET DANS LA RÉGION NoRd-EsT du BRÉSIL: UNE ETUde ETHNOLINGUISTIQUe

\section{Maranúbia Pereira Barbosa DOIRON * Vanderci de Andrade AGUILERA **}

Resumo: Este estudo trata das variantes lexicais para o calçado alpargata no Estado do Paraná e na região Nordeste do Brasil, sob um viés etnolinguístico. Tomamos como corpus os registros obtidos a partir da questão de número 276 do Questionário Semântico-Lexical do Atlas Lingüístico do Paraná ALPR, de autoria da professora Vanderci de Andrade Aguilera (1994), da Universidade Estadual de Londrina (UEL), e as variantes lexicais para o referido calçado encontradas em duas obras literárias de autores nordestinos, no caso, Fogo Morto, de José Lins do Rego (2009), e Vidas Secas, de Graciliano Ramos (1969). Nessas obras, a alpargata tem papel de destaque, refletindo sua importância no vestuário daquela região, ao menos até meados do século $\mathrm{XX}$. Buscamos investigar eventuais similitudes ou diferenças existentes entre as variantes lexicais para o calçado mencionado, fornecidas pelos informantes paranaenses, e aquelas descritas nas obras dos escritores Rego e Ramos. Priorizamos, em ambas as fontes - a linguística e a literária - a análise etnolinguística e lexicológica das unidades lexicais e o contexto em que foram registradas. O estudo demonstrou que, partindo da unidade lexical alpercata

\footnotetext{
* Doutoranda em Estudos da Linguagem; mestre em Estudos da Linguagem pela Universidade Estadual de Londrina (UEL, 2009); graduação em Comunicação Social Jornalismo (UEL, 1998). Contato: maranubiapereira@hotmail.com.

** Doutora em Letras pela Universidade Estadual Paulista Julio de Mesquita Filho Assis (1990). Docente da Universidade Estadual de Londrina. Contato: vanderci@uel.br.
} 
e suas variantes fonéticas, que são as mesmas nos dois corpora, e das variantes lexicais populares constantes do ALPR, o calçado tem estética e função diferentes nas localidades estudadas.

Palavras-chave: Variantes lexicais. Alpargatas. Estudo etnolinguístico.

Resumé: Cette étude concerne les variantes lexicales pour le mot espadrilles dans l'Etat du Paraná et dans la région Nord-Est du Brésil, sous un regard ethnolinguistique. Le corpus est composé par les donnés obtenues à partir de la question numéro 276 du Questionnaire Semantique-Lexical de l'Atlas Linguistique du Paraná (ALPR), dont l'auteur est le professeur Vanderci de Andrade Aguilera (1994), de l'Université de l'Etat de Londrina, autant que les variantes lexicales pour le mot espadrilles trouvées dans deux ouvrages littéraires d'auteurs originaires du Nord-Est du Brésil - Fogo Morto, de José Lins do Rego (2009) et Vidas Secas, de Graciliano Ramos (1969). Dans ces livres, les espadrilles jouent un rôle fondamental, tout en reflétant son importance dans le vestiaire de cette région, du moins jusqu'à moitié du XXème siècle. On rechercha des éventuelles ressemblances ou différences existentes entre les variantes lexicales de la chaussure mentionnée par les informateurs "paranaenses" et le modèle cité dans les ouvrages des écrivains Rego et Ramos. Dans les deuxs sources - la linguistique et la littéraire - on privilégia l'analyse semantique des unités lexicales et le contexte dans lequel elles ont été enregistrées. L'étude démontra que l'unité lexicale espadrilles et ses variantes phonétiques similaires dans les deux corpora, aussi que les variantes lexicales populaires présentes dans l'Atlas Linguistique du Paraná (ALPR). En dépit des simitudes l'esthétique et la fonction des espadrilles ne sont pas les mêmes dans les localitées concernées.

Mots-clés: Variantes lexicales. Espadrilles. Etude ethnolinguistique.

\section{Da Apresentação}

Quantos significados cabem num signo linguístico? Em que circunstâncias o mesmo signo pode ter acepções diferentes? Questões desse gênero embasam um sem número de pesquisas no âmbito da Linguística, principalmente as que contemplam a Dialetologia e a Etnolinguística, como é o caso deste artigo. Propomos aqui, a partir de respostas dadas à questão de número 276 do Questionário Semântico-Lexical do Atlas Lingüístico do 
Paraná - ALPR (AGUILERA, 1994) - questão essa que aponta as variantes lexicais atribuídas a um tipo específico de "calçado antigo, de lona, de corda trançada", verificar se os registros fornecidos pelos informantes paranaenses encontram respaldo no Nordeste do Brasil. À guisa de contraponto, tomamos como fontes, além do ALPR, dois romances do chamado regionalismo brasileiro, sendo eles: Fogo Morto, de José Lins do Rego (2009) e Vidas Secas, de Graciliano Ramos (1969), cujas obras destacam a popularidade do calçado designado como alpargata junto à população nordestina, notadamente, o sertanejo. A partir das designações lexicais escolhidas pelos dois escritores, buscamos analisar, sob um viés etnolinguístico, as variantes lexicais para esse calçado nas referidas obras e no interior paranaense.

A proposta de um estudo dialetal, com um viés para a Etnolinguística e a Lexicologia, que encampe obras de linhas diferentes - um atlas linguístico e romances da literatura brasileira - e, por isso, passível de suscitar questionamentos acerca da pertinência de confrontar as duas áreas justifica-se na medida em que a alpargata, calçado popular em todo o Brasil, além de ter sido registrado nos inquéritos do ALPR, teve particular destaque na indumentária nordestina, como atesta a produção literária de diversos escritores oriundos dessa região.

Considerando isso, procedemos ao levantamento das variantes lexicais para esse calçado encontradas no ALPR, tencionando apontar quantas e quais delas constavam de Fogo Morto e Vidas Secas. Em seguida, passamos à análise das unidades lexicais documentadas pelos inquiridores do ALPR, bem como daquelas encontradas nos dois romances, objetivando-se, como já exposto, saber se as designações atribuídas ao calçado seriam as mesmas em ambos os corpora.

Priorizamos a análise etnolinguística das variantes lexicais mais recorrentes, consideradas, particularmente, do ponto de vista contextual. Ao final, verificamos o quão original, inusitado e inventivo pode ser o uso que os falantes do português brasileiro fazem do léxico, quaisquer que sejam suas regiões de origem.

\section{Das Notas sobre o Percurso Histórico da Alpargata}

Antes que passemos à análise dos corpora, julgamos necessário introduzir algumas notas históricas sobre o aparecimento do calçado designado como alpargata, com ênfase em seu uso no Brasil. A enciclopédia Larousse (1987a, p. 210, grifos do original) traz essa definição para o calçado: 
Alparcata ou alpargata (substantivo feminino): sandália de couro que se prende ao pé por meio de correias e cujos modelos se têm multiplicado pela industrialização. É o mais antigo calçado em pleno uso moderno: clássico no Egito ptolomaico, foi levado pelos árabes a Portugal. Consta de duas faixas estreitas, que partem dos lados da palmilha, e se cruzam sobre o peito do pé. Os negros africanos (escravos vaqueiros e tangerinos) o usavam muito na pecuária, e ainda é muito encontrado no Brasil de hoje; calçado que já era quadrissecular no início da era cristã. (Variantes: alparca, alpercata, alpregata, paragata, pargata, pracata, pragata)

Os primeiros registros da unidade lexical alpargata, conforme a enciclopédia citada, definem um modelo em couro surgido num período histórico em que o homem já dominava técnicas que lhe permitiam a confecção de artefatos a partir da pele ${ }^{1}$ de animais. Conhecida desde a era ptolomaica $^{2}$, introduzida junto com os árabes ${ }^{3}$ na Península Ibérica, a partir de 711 d.C., chegou ao Brasil pelas mãos dos colonizadores portugueses, no século XVI.

As referências ao uso desse calçado no período colonial brasileiro encontram lugar em muitas gravuras da época, como a de Debret (1975), figura 1, do início do século XIX, em que se vê um feitor castigando um escravo. O modelo de alpargatas usado pelo feitor, de correia presa sobre o peito do pé, à moda de muitos chinelos atuais, parece ser em tecido, dado o tom azulado, denotando que, apesar da precariedade instaurada no Brasil Colônia, era possível encontrar alguns produtos têxteis manufaturados, como o retratado na gravura (figura 1).

1 Tópico acerca do advento da domesticação de animais, disponível em (LAROUSSE, 1987b, p. 1987-1988).

${ }^{2}$ Diz respeito a uma dinastia de soberanos que reinaram sobre o Egito Antigo entre 304 a.C e 30 a.C. (LAROUSSE, 1987c, p. 4922).

3 Tópico sobre a presença árabe em Portugal consta em Saraiva, 1983. 


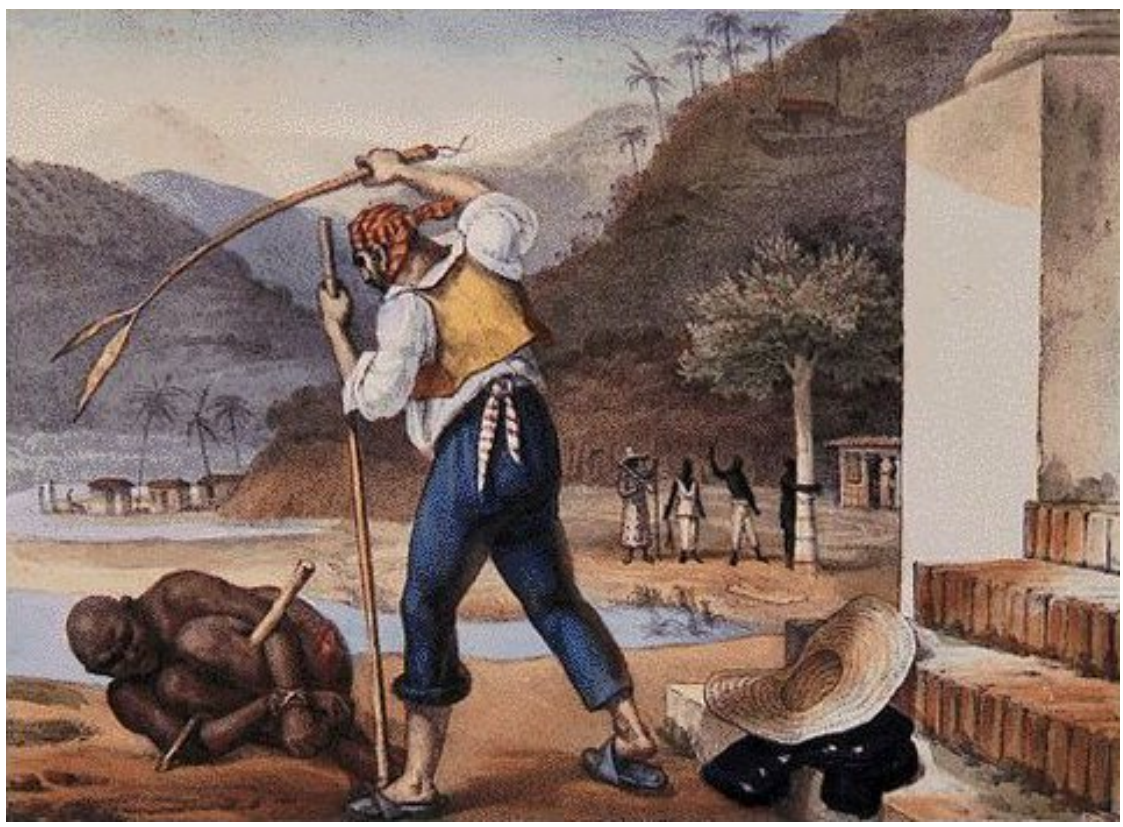

Fonte: <pt.wikipedia.org/wiki/Jean-Baptiste_Debret>.

Figura 1 - Gravura de Debret (1975)

Bem antes de Debret chegar ao Brasil, em 1816, como integrante da missão artística francesa que criaria a Academia de Belas Artes, há menção sobre alpargatas na literatura informativa do século XVI, especificamente em cartas do padre José de Anchieta, escritas depois de sua chegada ao Brasil, na metade do referido século. Numa delas, expedida da região de Piratininga, que, em 25 de janeiro de 1554, viria a abrigar o Colégio e a Vila de São Paulo, o religioso relata ao padre geral da Companhia de Jesus, em São Vicente, alguns detalhes sobre o trabalho duro dos missionários. A carta, reproduzida aqui com grafia da época, data de $1^{\circ}$ de junho de 1560.

Para não deixar de dizer, pois, quasi nenhuma arte das necessarias para o comum uso da vida deixam de fazer os Irmãos; fazemos vestidos, sapatos, principalmente alpercatas de um fio como canhamo, que nós outros tiramos de uns cardos lançados n'agua curtidos, cujas alpercatas são mui necessárias pela aspereza das selvas e das grandes 
enchentes d'agua: é necessário passar muitas vezes por grande espaço até a cinta, e algumas vezes até o peito, barbear, curar feridas, sangrar, fazer casas e cousas de barro, e outras semelhantes cousas não se buscam fóra, de sorte que a ociosidade não tem lugar algum na casa. (ANCHIETA, 1933, p. 151).

As alpargatas, de acordo com o relato do jesuíta, eram confeccionadas artesanalmente a partir de fios extraídos de uma planta que lembrava a ele o cânhamo. Não há referências, nas cartas de Anchieta, a modelos desse calçado em couro, talvez porque essa matéria-prima, mais elaborada, demandasse um número maior de ferramentas, raras na Colônia seiscentista e, sem dúvida, mais tempo e maior habilidade por parte do artesão. As alpargatas, em que pese a relativa fragilidade do tecido, eram o único meio que permitia ao usuário embrenhar nos matos e enfrentar as intempéries sem sair com os pés muito estropiados.

De todo modo, durante o povoamento do território brasileiro, as alpargatas de fibra têxtil, mesmo grosseiras e mal acabadas, eram um luxo que poucos podiam se dar. Fidalgos, colonos, padres e degredados, ao menos no quesito calçado, estavam todos no mesmo nível, ou seja, andavam mesmo era de pés no chão. Freyre (1981, p. 39) relata que à época, os colonos do século XVI, "mesmo 'os mais ricos e honrosos" e os missionários [andavam] de pé descalço, à maneira dos índios; costume que parece ter-se prolongado ao século XVII e aos próprios fidalgos olindenses”.

Segundo Freyre (1981), se os colonos andavam "à maneira dos índios”, não o faziam por gosto, mas por pura necessidade. Face à penúria generalizada, andar calçado, salienta o sociólogo, era o de menos. Notas sobre alpargata feita de couro são praticamente inexistentes durante o período inicial de povoamento do Brasil. Descrições do calçado nesse material começam a aparecer em textos bem mais tardiamente, citadas por cronistas e escritores, como José de Alencar, que fala de alpargatas em couro no romance Til, lançado em 1872.

As mangas da camisa, tinha-as enroladas até o cotovelo, bem como a parte inferior das calças que arregaçava cerca de um palmo. Usava de

${ }^{4}$ Freyre (1981), nessa passagem de Casa Grande e Senzala, faz referência a missionários como Anchieta, cuja obra consta da bibliografia utilizada neste artigo. 
alpargatas de couro cru e chapéu mineiro afunilado, cuja aba larga e abatida ocultava-lhe grande parte da fisionomia. (ALENCAR, 1977, grifo nosso).

O personagem, a julgar pela descrição de sua vestimenta, não parece ser alguém de classe social mais abastada, de onde se infere que o calçado era comum entre trabalhadores e pessoas de situação financeira inferior. Esse romance de Alencar, ambientado numa fazenda de Piracicaba, cidade do interior paulista, sugere que a região Sudeste, no século XIX, período em que se passa a narrativa, recebia um grande fluxo de migrantes e imigrantes. Essa rotatividade parece indicar que a alpargata de couro já era um calçado conhecido em todo o País.

\section{Do Atlas Lingüístico do Paraná}

Fruto da tese de doutorado de Aguilera ${ }^{5}$, o Atlas Lingüístico do Paraná, doravante, ALPR, foi publicado pela Imprensa Oficial do Estado do Paraná em 1994. A autora tomou por base os pontos linguísticos apresentados por Nascentes (1958), que propôs uma rede formada por 24 municípios, estendendo-a para um total de $65^{6}$. De uma extremidade a outra do Estado, do município de Diamante do Norte (Ponto 1, na região Norte) até Guaraqueçaba (Ponto 65), no litoral, perfazendo cidades do Centro, do Sul, Norte e Oeste, o ALPR considerou os aspectos geográficos, étnicos e históricos das localidades inquiridas.

Para a elaboração do questionário, Aguilera partiu do rol de questões proposto por Caruso (1984), autor do Questionário do Atlas Lingüístico do Estado de São Paulo. A ligação histórica entre os Estados de São Paulo e Paraná, a proximidade geográfica, a possibilidade de cruzar dados e elaborar estudos comparativos foram levados em conta na fase da escolha do questionário. Os inquéritos contemplaram dois campos semânticos, sendo eles:

${ }^{5}$ A tese foi defendida por Aguilera em 1990, na Universidade Estadual Paulista Júlio de Mesquita Filho - UNESP, campus de Assis-SP.

${ }^{6}$ A rede de pontos linguísticos do ALPR, bem como a de Nascentes (1958), constam do anexo. 
i) terra - natureza, fenômenos atmosféricos, astros, tempo e demais temas relacionados; a flora, com destaque para plantas medicinais.

ii) homem - partes do corpo, funções, doenças; vestuário e calçados; agricultura, instrumentos agrícolas; brinquedos, jogos infantis; lendas, superstições.

Em cada uma das 65 localidades foram selecionados dois informantes, num total de 130. A autora designou como A o informante do sexo feminino, e como B, o do sexo masculino, que, em linhas gerais, preencheram as características recomendadas nas diretrizes para a elaboração de atlas linguísticos (SILVA NETO, 1958): pessoas naturais da localidade e, se possível, com os pais também nascidos no lugar; pessoas que nunca viajaram, ou, se o fizeram, que não tivessem permanecido muito tempo fora de sua região; indivíduos com pouco ou nenhum contato com a ensino formal institucionalizado.

Transcritos, compilados, analisados, os dados geraram 6 cartas que apresentam a localização geográfica do Paraná no Brasil, as microrregiões, a rede de pontos, o número de habitantes de cada um dos municípios inquiridos, a equipe de entrevistadores, além de 191 cartas linguísticas: as cartas lexicais estão numeradas de 1 a 92; as cartas fonéticas, de 93 a 162; e as cartas isoglóssicas, de 163 a 191.

\section{Das Variantes Lexicais para Alpargata no ALPR}

A questão 276 do ALPR propunha buscar variantes lexicais para um tipo de calçado: a alpargata. Para tanto, os entrevistadores sugeriam os semas: 'calçado antigo', 'de lona' e 'sola de corda trançada'. Entre as respostas citadas pelos informantes, Aguilera selecionou as 11 unidades lexicais mais recorrentes, as quais foram reunidas na carta número 80 do ALPR, reproduzida aqui. 


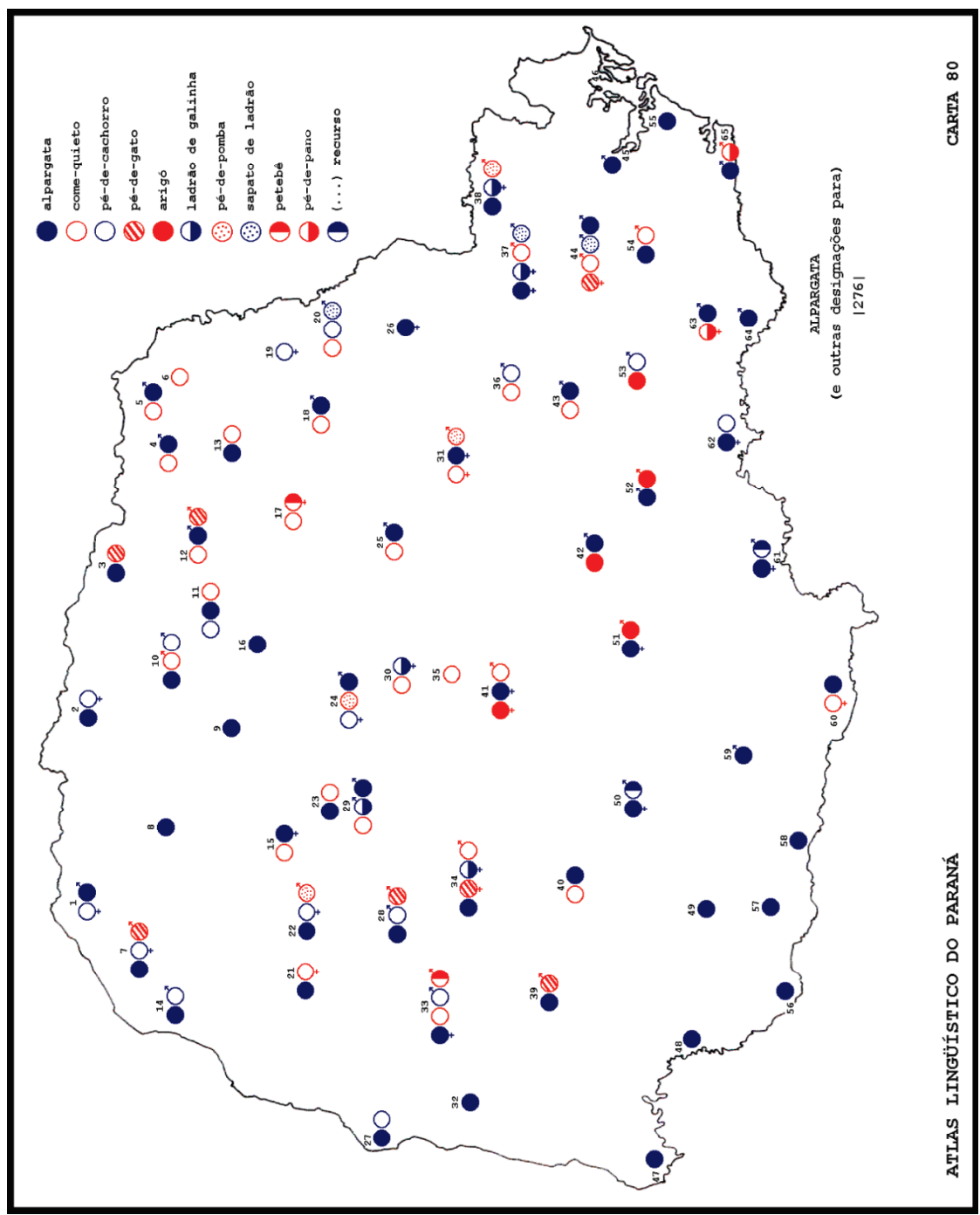

Fonte: Atlas Lingüístico do Paraná (AGUILERA, 1994).

Figura 2 - Carta 80 do ALPR

$\mathrm{Na}$ carta, em ordem de recorrência, as unidades lexicais foram assim listadas: 


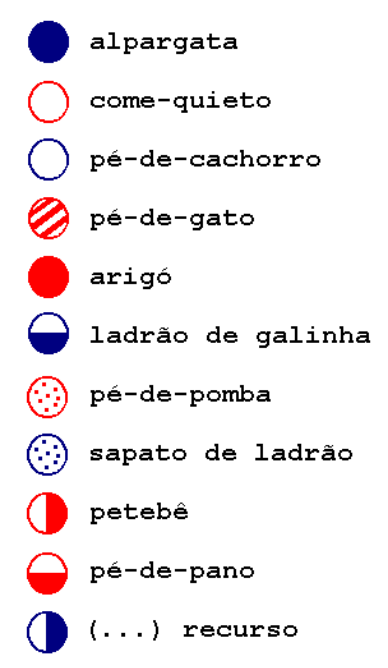

Fonte: Atlas Lingüístico do Paraná (AGUILERA, 1994).

Figura 3 - Legenda da carta 80 do ALPR

Conforme se vê no mapa, de um total de 65 pontos inquiridos, a unidade lexical alpargata não foi registrada pelos informantes em apenas quatro localidades: Jacarezinho (ponto 6), São Jerônimo da Serra (ponto 17), Siqueira Campos (ponto 19) e Castro (ponto 36). Entre as menos mencionadas, houve três designações com apenas dois registros: último recurso, em Laranjeiras do Sul (ponto 50) e União da Vitória (ponto 61); pé-de-pano, no município de Lapa (ponto 63) e em Guaratuba (ponto 65), as duas situadas no litoral; e, por fim, a designação petebê, encontrada em São Jerônimo da Serra (ponto 17) e Assis Chateaubriand (ponto 33). Em relação a essa última variante lexical, note-se que ela foi registrada em dois municípios relativamente distantes um do outro ${ }^{7}$, enquanto as duas primeiras designações foram verificadas em localidades próximas, Laranjeiras do Sul e União da Vitória, no Sul do Estado, Lapa e Guaratuba, ambas no litoral, respectivamente. Unidades lexicais que tiveram apenas um registro foram deslocadas para as notas, não constando da carta 80. Um olhar etnolinguístico

${ }^{7}$ A localização dos municípios pode ser verificada na carta IV, em anexo. 
sobre as variantes lexicais apresentadas no ALPR revelou-se profícuo, como pode ser observado na análise que se segue.

Alpargata - segundo o dicionário Aulete (s.d.), substantivo feminino, do árabe al-pargat, uma "espécie de calçado cuja sola se ajusta ao pé por meio de tiras de couro, borracha ou algum tecido". O dicionário Michaelis (s.d.) traz duas classificações: do árabe hispânico al-bargât. 1 Sandália, geralmente com cabedal de tecido e sola flexível de corda ou palha que se ajusta ao pé por meio de correias ou cadarço. 2 Calçado leve, de lona, com sola de borracha, couro ou outro material. Os dois dicionários trazem as mesmas variantes fonéticas: alparca, alparcata, alpercata, alpergata, pragata, percata, precata. Ferreira (2004) lematiza como alpercata, significando "sandália sem salto que se prende ao pé por tiras de couro ou de pano; lorê". Inclui, ainda, as variantes e formas paralelas: albarca, alparca, alparcata, alpargata, alpergata, apragata, paragata, pracata, pargata, pragata e o brasileirismo loré.

Nas notas ${ }^{8}$ referentes à carta 80 estão as variantes lexicais dicionarizadas, transcritas aqui em conformidade à fala dos informantes: alpargata, alpragata, apargata, pargata, paragata, paragato, pragata, pregata. Alguns informantes indicaram como resposta uma unidade lexical composta: alpargata roda. Consideramos que essa designação, dada a gama de sentidos levantados, mereceria uma análise à parte.

Os entrevistadores do ALPR, ao proporem os semas 'calçado antigo', 'de lona' e 'sola de corda trançada', repassaram a concepção de uma peça do vestuário popularizada no Sul do Brasil. Da maneira como foi apresentada a questão, os elementos fizeram lembrar aos informantes o modelo de calçado comercializado pela fábrica de produtos têxteis, a São Paulo Alpargatas Company ${ }^{9}$, que, no início do século XX, se chamava Alpargatas Roda, Lonas e Encerados. Fundada na capital paulista em 1907, por um imigrante escocês, em parceria com um grupo inglês, a fábrica era produtora de lona, tecido forte e grosso feito de algodão, juta ou outra fibra similar. Da lona teciamse encerados utilizados nos terreiros para a secagem dos grãos de café principal baluarte da economia brasileira no início do século - e uma alpargata rústica, concebida especificamente para os trabalhadores desse setor agrícola.

${ }^{8}$ As notas, transcritas na página 182 do ALPR, constam das citações neste artigo.

${ }^{9}$ Informações sobre a fábrica São Paulo Alpargatas Company constam do site Alpargatas, disponível em <www.alpargatas.com.br>. Acesso em: 20 abr. 2011. 
Segundo o que se propagava na época, o calçado, macio e de matéria-prima natural, era perfeito porque não amassava os grãos de café durante a colheita nem quando expostos à secagem. O nome fantasia do calçado - Alpargatas Roda - sofreu, portanto, um processo metonímico, ou seja, o emprego de uma palavra com o significado de outra em vista de uma relação de causalidade ou de implicação mútua entre o que elas representam, estendendo-se, genericamente, a todos os outros calçados que possuíam mais ou menos o mesmo formato, pouco importando a marca ou a finalidade, se adquirida para o trabalho ou lazer. É nessa situação contextual, de reportar a marca ao objeto propriamente dito, que alguns informantes forneceram as seguintes respostas, reproduzidas das notas do ALPR (AGUILERA, 1994, p. 182):

02 (inf. B): (...) Reformulando-se a questão, registrou: "épargata roda". 08 (inf. A): "paragato, paragata rode".

13 (inf. A): A primeira resposta foi: "eles falava de : alpargata roda". 25 (inf. B): Na repergunta comentou: "é pragata roda queis tratava antigamente (...)".

29 (inf. B): "pargata ródia (...)".

34 (inf. A): “primeiramente que eu conheci aquele lá por pragata roda (...) Depois disapareceu aquele lá. (...)"

40 (inf. A): Na repergunta ocorreu: "a pragata roda", comentando que a sola é de: "barbante".

43 (inf. B): Para 'outro nome': "pragata roda".

46 (inf. A): “(...) sapata roda que diziam naquele tempo (...) Eu vi lá assim, eu cunheci desse sapato, mas não carcei”.

48 (inf. B): “alpragata". Perguntada por 'outro nome', comentou: "cono [= quando] apareceu era alpragata o nome. Depois modificaro, ponharo um assim, que nem o seu assim, esse aí é tênis, mas aquela era de barbante, de corda, aquela [era] alpragata, alpragata roda".

54 (inf. A): "pargata roda".

(inf. B): "alpacatas rodas se chama aqui".

60 (inf. A): Na repergunta registrou: "nóis conhicia, nós dizia assim, né, paragata, paragata roda".

O fato de atribuir o nome da marca de fantasia ao calçado pode ainda ser constatado em outras respostas dadas por alguns informantes. 
02 (inf. B) : “aqui(lo) lá é o conga”. Reformulando-se a questão, registrou: "é pargata roda".

11 (inf. A) : A segunda resposta foi: "sete vida".

21 (inf. A) : "Referiu-se ainda ao: "quichute e sete vida".

31 (inf. B) : A primeira resposta foi: "conga".

33 (inf. B) : A resposta completa foi: "eu cunheço aquele [por] quichute (...)".

42 (inf. B) : "ma(s) não é o quichute?"

51 (inf. A) : “é o conga?” Para 'outro nome’: “eu conheço por conga aquela... pargata rode".

58 (inf. B) : "aquela é a conga?"

Os registros conga, sete vidas e quichute, que designam referentes distintos das variantes lexicais atribuídas ao calçado designado por alpargata, remetem igualmente a algumas marcas de calçados de lona, e parecem ter sido associadas pelos informantes ao carro-chefe da fábrica paulista, as Alpargatas Roda.

O calçado de marca Kichute, misto de tênis e chuteira, foi lançado também pela São Paulo Alpargatas Company na década de 70, na esteira do tricampeonato de futebol conquistado pelo Brasil. De cor preta, o modelo, também feito de lona, como as alpargatas, mas com cravos de borracha e longos cadarços, alcançou grande popularidade entre os meninos, sendo usado, especialmente, para jogar futebol. Já o modelo Conga, adotado como parte de uniformes escolares, geralmente nas cores preta e azul-marinho, fabricado em lona, amarrado com cadarços, mas sem os cravos de borracha, aproximava-se mais do formato dos tênis e sapatilhas atuais, apesar de o solado ser baixo como o das alpargatas. Importante observar que as Alpargatas Roda, inicialmente produzidas com sola de corda ou barbante, a partir da modernização da indústria brasileira, em meados dos anos 50, ganharam solado emborrachado, como os novos modelos Kichute e Conga. 


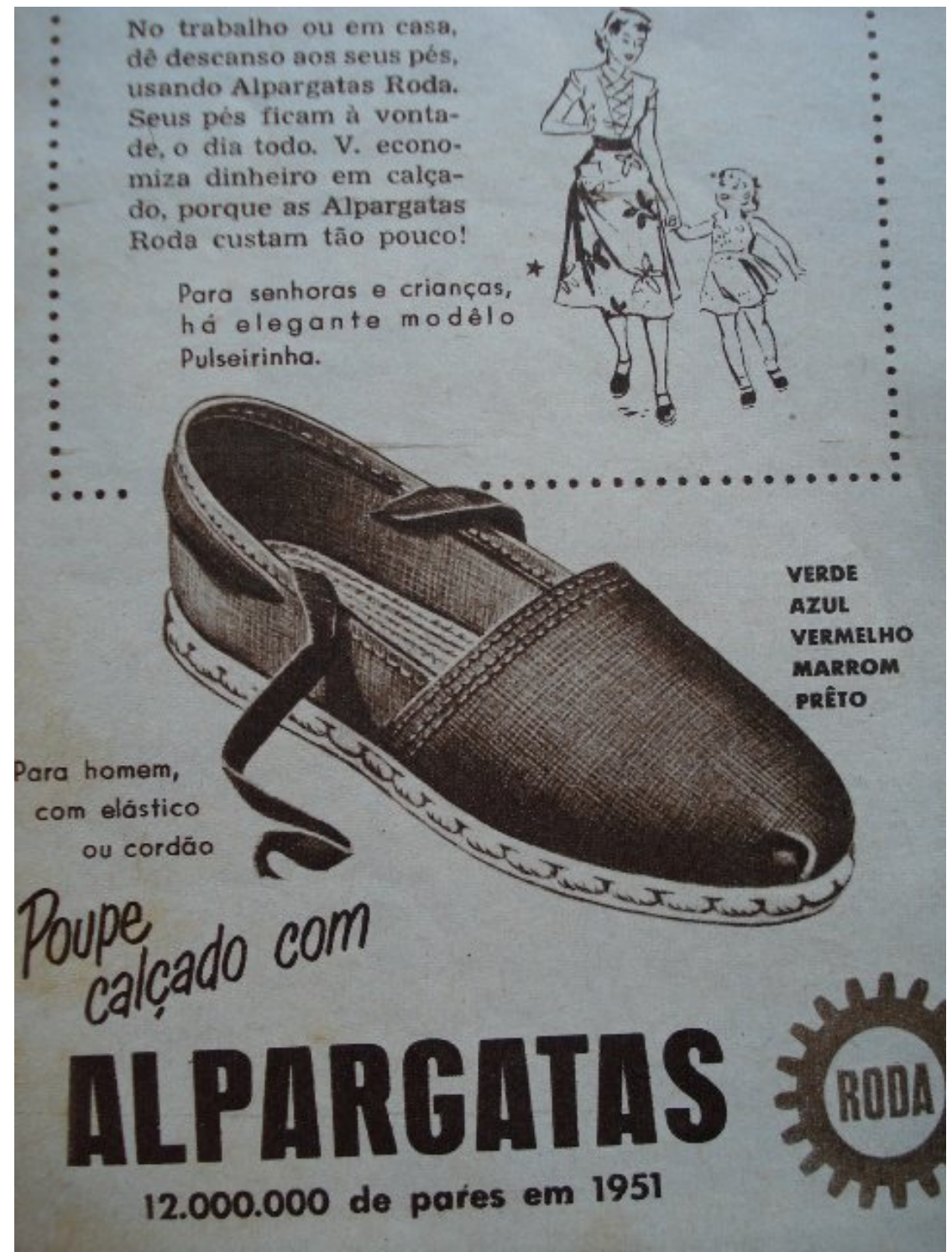

Fonte: O Reclame nos tempos idos, 13 out. 2011.

Figura 4 - Reprodução do anúncio do calçado Alpargatas Roda, tal qual era comercializado nos anos 50 


\section{recuse imitações!}
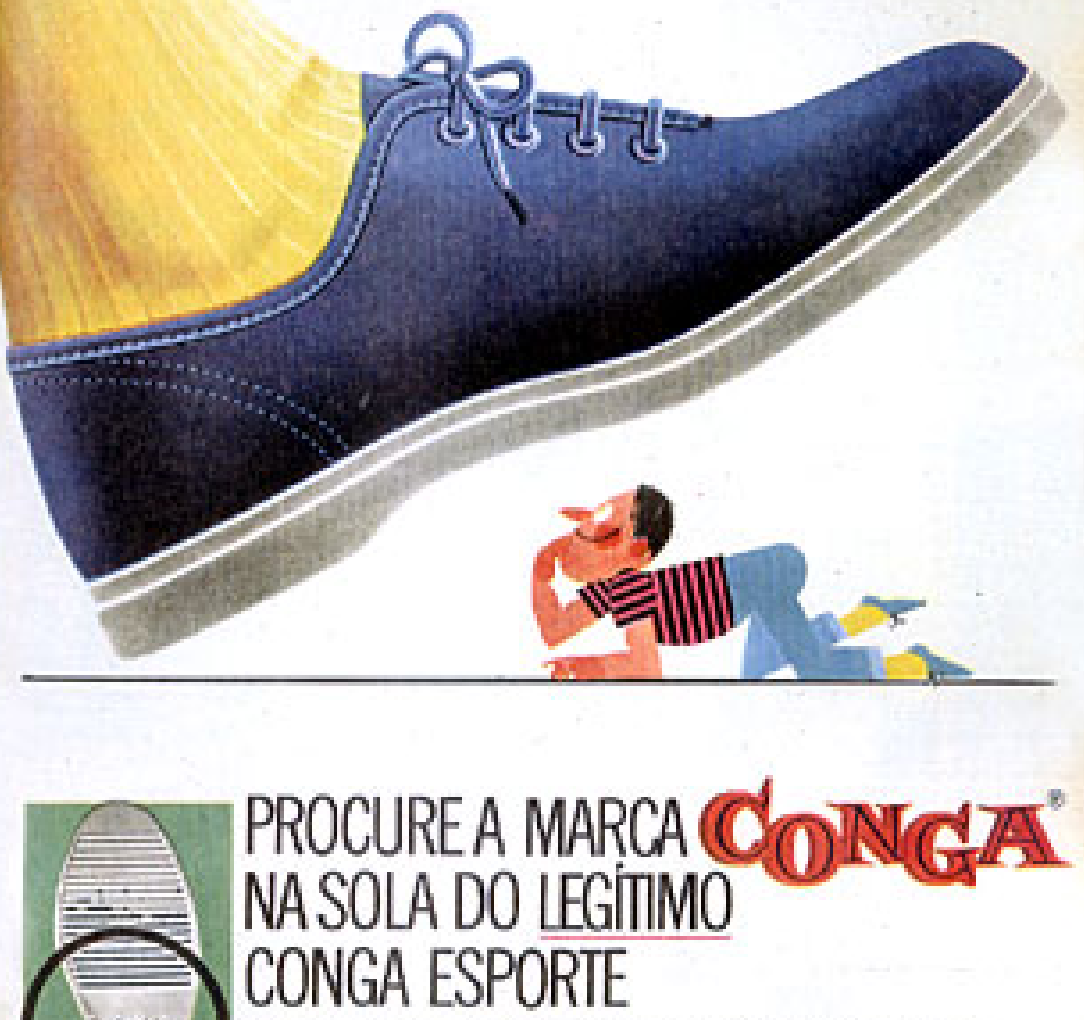

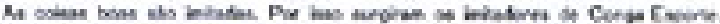

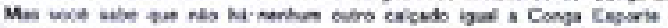

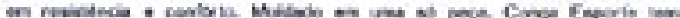

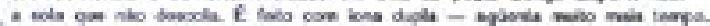

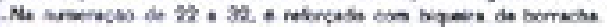

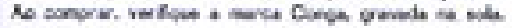

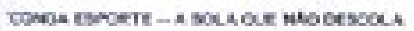

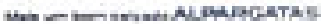

Fonte: http://meusegundocaderno.blogspot.com/2009/10/propagandas-dasantigas.html

Figura 5 - Anúncio do calçado Conga veiculado nos anos 60 
Além das Alpargatas Roda, do Kichute e do Conga, a São Paulo Alpargatas Company produzia o calçado Sete Vidas, outra versão similar do modelo de alpargatas de lona. De custo baixo, acessível às classes menos privilegiadas, as quatro marcas de calçados foram associadas ao que se entendia por alpargata, por isso a menção dos informantes do ALPR, mesmo que, no caso de Kichute, Conga e Sete Vidas, não correspondessem exatamente aos semas 'calçado antigo', 'de lona' e 'sola de corda trançada'.

Ponderando-se sobre o que teria motivado a escolha desses nomes de fantasia por parte da São Paulo Alpargatas Company, verificamos que, à época do lançamento desses calçados, era relativamente comum alguns produtos industrializados serem escritos com letras ditas estrangeiras, ou seja, aquelas que não constavam do alfabeto português. No exemplo do calçado Kichute, a letra "K" fazia as vezes do advérbio "QUE”, geralmente utilizado para introduzir orações exclamativas, com o sentido de "QUÃO”. Assim, o Kichute aludia a um "que chute!", tal qual o refresco Ki-Suco, exemplo de outro produto da mesma época, reportava a um "que suco!". O emprego da letra "K", bem como o "W" e o "Y" em marcas de fantasia, muitas vezes tinham por função remeter a palavras estrangeiras, sugerindo status e modernidade aos nomes de coisas e de pessoas. A despeito de não constar do site da São Paulo Alpargatas Company nenhuma indicação acerca de como foi criada a marca Conga, o nome pode ser uma referência à dança de origem cubana que, segundo o Aulete (s.d.), "consiste em andar no ritmo e marcar o compasso com movimento brusco ou sacudidela do corpo". A marca Conga pode ter sido justamente associada aos passos ritmados e ágeis da dança. O calçado Sete Vidas, com significado um pouco mais evidente, seria uma alusão às propaladas sete vidas dos gatos, ou seja, o calçado, como sugeria o fabricante, teria uma vida útil fora do comum.

Quanto à designação come-quieto, registrada em 28 localidades, a segunda mais mencionada pelos informantes do ALPR, ela é definida em Ferreira (1986) como brasileirismo popular para "calçado de lona, sapato tênis". $\mathrm{Na}$ edição de 2004, Ferreira registra apenas com o significado de "tênis". $\mathrm{Na}$ segunda entrada, em ambas as edições consultadas (1986 e 2004), come-quieto consta com o significado de "indivíduo discreto, que não alardeia as suas conquistas amorosas". Observe-se que o teor da segunda definição - o indivíduo conquistador e reservado - em analogia à alpargata, deve-se ao fato de que o calçado de lona, por ser constituído de material leve, permite que a pessoa se locomova sem estardalhaço, que vá para lá e para cá de 
mansinho, sem apregoar sua presença, exatamente como nesse comentário do Informante B (ponto 54), arrolado nas notas do ALPR: "nói chamava (a)qui come-queto, podia andá que num fazia barulho, né”.

Essa circunspecção, por assim dizer, da alpargata, que possibilita maciez, habilidade e ligeireza no andar, é ampliada para esperteza e velhacaria no conceito de ladrão de galinha, outra variante lexical citada pelos informantes do ALPR. Um deles (Informante A, ponto 38) justificou assim sua resposta: "chamavam ladrão de galinha, (...) num fazia barulho". Interessante notar que se trata de portar alpargatas para roubar galinhas, um bem de pouca monta, e não para roubar bancos ou joalherias, pois nessa empreitada, por certo, seria necessário estar equiparado de outro tipo de calçado mais robusto, além do que, o status de um ladrão de galinhas sugere um indivíduo de parcos recursos, aparentemente sem condições de adquirir outros pares de calçados que não os de lona. A variante sapato de ladrão também se insere nesse contexto, de ser um tipo de sapato com o qual um indivíduo pode se lançar à prática de atos ilícitos e se evadir do local sorrateiramente. Isso foi comentado pelo Informante B, no ponto 20: “(...) sapato de ladrão”. Indagado sobre o porquê do último nome, respondeu: "porque não fazia buia”, ou seja, "bulha", como quer a norma padrão. O Informante A (ponto 15) fez uma consideração semelhante: “... é roba galinha. (...) ... muitos fala, pa robá esse é fáci num fai baruio".

A unidade lexical pé-de-cachorro refere-se ao design do calçado designado como alpargata: ovalado e fechado na parte da frente, faz lembrar a alguns a pata do cão. A referência ao formato aparece em outros comentários: "muitos tratava pão doce" (Informante B, ponto 26). Os pães doces e brioches costumam ter forma arredondada e serem macios, o que poderia explicar o termo. Por sua vez, o nome pé-de-gato ${ }^{10}$ alude ao formato da alpargata e ao andar aveludado dos felinos. Essa faculdade de caminhar em surdina também parece explicar a designação pé-de-anjo, citada pelo Informante A do ponto 52. Entretanto, o Aulete (s.d.) traz outras definições para o nome: "pé de anjo. 1. Bras. Tênis branco. 2. Pop. Pé demasiado grande”. A variante lexical

${ }^{10}$ Ferreira (2004) registra a forma pé-de-gato, como termo da botânica, sem relação com o calçado. Outras designações: pé-de-anjo consta com o significado de tênis branco; pé-de-cachorro como indivíduo reles, sem importância; pessoa feia ou pouco atraente; e arigó, como indivíduo rústico, matuto, caipira. Não constam deste dicionário pé-de-pomba, pé-de-pano e petebê. 
dada pelo informante indica maior ligação com entidades etéreas, pela propriedade volátil de locomoção desses seres, do que com o tamanho ou a cor da alpargata. Já a designação pé-de-pomba não parece se enquadrar na analogia formato e feitio. Todavia, se a ponta das alpargatas não evoca pés de pomba ou pombo, pode ser então que a designação venha da relação entre o andar silencioso dessas aves e a pisada sutil do calçado de lona. Quanto à unidade lexical pé-de-pano, obviamente, refere-se ao tecido de que são feitas as alpargatas: a lona.

A designação arigó, registrada pelos inquiridores em cinco pontos da região Centro-Sul, tem duas entradas na enciclopédia Larousse, ambas classificadas como brasileirismos: "1. Indivíduo que trabalha na construção de uma estrada. 2. Simplório, rústico.” A segunda definição é dada como sendo própria do Centro e do Sul do Brasil. Com efeito, inicialmente, as alpargatas eram destinadas à mão de obra rural, especificamente aos trabalhadores da cultura de café, mas, logo depois, difundiram-se tanto elas quanto os similares, voltados a pessoas em outros setores da economia. Entre esses trabalhadores estavam os empregados na construção de Brasília, que nos anos 50 se punham à obra com seus Sete Vidas nos pés, conforme informado no site da São Paulo Alpargatas Company. Bem antes do advento da construção de Brasília, nos primórdios do século XX, um modelo ainda mais tosco de alpargatas já era utilizado por trabalhadores, incluindo crianças que constituíam mão de obra comum em fábricas. Em um artigo do jornal Folha de S. Paulo (FERRAZ, 2003) sobre a memória da industrialização em São Paulo, capital, consta que...

O ambiente [nas fábricas] era o pior possível. Calor intolerável, dentro de um barracão coberto de zinco, sem janelas nem ventilação. [...] Os cacos de vidro espalhados pelo chão representavam outro pesadelo para as crianças, porque muitas trabalhavam descalças ou com os pés protegidos apenas por alpercatas de corda, quase sempre furadas.

A clientela em potencial das alpargatas vinha, portanto, do operariado, pessoas oriundas de camadas sociais menos favorecidas, simples no trato. Logo, a variante arigó, registrada no ALPR, designando o indivíduo "simplório e rústico", passou, num processo metonímico, a ser associada à alpargata. 
A unidade lexical petebê, encontrada em apenas duas localidades, vem corroborar o baixo prestígio da alpargata. Essa variante é classificada como gíria por Ilari (2001). No excerto abaixo, achou-se por bem deixar outros exemplos que acompanham petebê, com o intuito de agregar mais informações ao tema:

Muitas gírias que já tiveram grande circulação no Brasil são hoje pouco conhecidas entre as gerações mais novas, e, quando usadas, conotam velhice. $[\ldots]$

XPTO (bonito, legal)

Marca barbante, petebêe (ruim, de má qualidade)

Fogo na roupa (levado)

Pão (rapaz bonito)

Xuxu (moça bonita, boazuda)

Babado (problema)

Bocomoco, Pedrobó (bobo)

(ILARI, 2001, p. 44, grifo nosso)

Em se considerando a citação, a qualidade inferior da alpargata justifica a alcunha de petebê, gíria que caiu em desuso. A variante lembra também o partido político conhecido pela sigla PTB $^{11}$, o Partido Trabalhista Brasileiro, fundado em 1945. A ocorrência lexical recurso, encontrada em dois pontos do ALPR, ratifica o descrédito. O Informante B (ponto 61) foi incisivo: "eu lá dizia o úrtimo recurso". No comentário, subentende-se que, para o informante, a alpargata seria o derradeiro expediente com o qual ele podia

${ }^{11}$ O PTB, fundado no Rio de Janeiro (então Distrito Federal), em 15 de maio de 1945, sob a inspiração de Getúlio Vargas, tinha como base eleitoral o operariado urbano, com forte ligação com os sindicatos. O PTB era, entre os grandes partidos de então, o mais à esquerda, e era constantemente acusado pelos opositores de ter políticas comunistas. O programa partidário do PTB pregava algumas reformas, como a urbana, a agrária e a educativa, e tinha ênfase no crescimento econômico, desenvolvimento industrial, nacionalização de recursos e na educação. Estava incluído no contexto populista que dominou a prática política a partir do Estado Novo em diante. Foi criado, entre outros motivos, para servir de anteparo, na classe popular e trabalhadora, à influência do Partido Comunista, e demais organizações de esquerda. (Adaptado de "Partido Trabalhista Brasileiro", Wikipédia (s.d.)). 
contar, pois, se possuísse meios, provavelmente teria outro tipo de calçado nos pés.

Se, por um lado, a alpargata tinha reputação de ser um produto ruim, por outro, alcançou tal nível de popularidade a ponto de a mesma qualidade ordinária ser tratada com complacência pelos consumidores. É com familiaridade e bom humor que os informantes se referem a ela, como nos comentários aqui destacados:

10 (inf. B) : “(...) a turma tirava sarro na gente quano ia em quarqué lugá lá. Quano via ca (...)quele no pé ficava pareceno tonto”.

15 (inf. B) : “(...) otos falava seca-poça”.

18 (inf. B) : "pé-de-chinelo (...)".

20 (inf. A) : "falava isparrama bosta (...)".

29 (inf. B) : "ladrão de galinha, dizer antigo tamém, brincadeira do povo, né".

33 (inf. B) : “(...) sofre sożinho”. Indagando-se o porquê do último nome, explicou: "sofre sozinho porque ce pensa que tá carçado e num tá nada. Num dá nem pa passá perto do ispinho que já finca tudo na gente. Intão ce tá co ele no pé, tá disfarçado, tá sofreno e num tá veno". (AGUILERA, 1994, p. 182).

Procedida a análise das variantes lexicais arroladas, concluímos, preliminarmente, que aquelas encontradas no ALPR dizem respeito, num primeiro momento, a um modelo específico patenteado pela São Paulo Alpargatas Company: as Alpargatas Roda. Num segundo momento, as variantes lexicais aludem a outras marcas de calçado com mais ou menos a mesma linha, todos produzidos pela mesma empresa. Finalmente, consideramos que os sentidos das unidades lexicais estão relacionados às características gerais de um tipo de calçado designado como alpargata, ou seja, sua finalidade de uso e suas propriedades estéticas.

\section{Das Variantes Lexicais para o Calçado Designado por Alpargata em Fogo Morto e Vidas Secas}

Considerado um dos expoentes da literatura regionalista brasileira, o romance Vidas Secas, do escritor Graciliano Ramos, foi publicado em 1938, alcançando logo de início grande repercussão. Natural de Quebrângulo, no 
Estado de Alagoas, Ramos, com linguagem seca e direta, narra o percurso de uma família de retirantes nordestinos durante a seca, delineando um perfil fidedigno da problemática social brasileira em sua face mais bruta.

Aclamado pela crítica desde a primeira edição, em 1943, Fogo Morto é considerado por críticos e leitores como a obra-prima do escritor José Lins do Rego, paraibano de Pilar. Com personagens densos e magistralmente construídos, o romance fecha o chamado ciclo da cana-de-açúcar, prosa ficcionista que teve como foco os engenhos de açúcar nordestinos: Fogo Morto expõe a decadência desse sistema de produção açucareira.

Como dito no início deste trabalho, objetivamos pontuar nos dois romances as variantes lexicais para um modelo de calçado designado como alpargata, visto que essa peça de vestimenta conheceu notável popularidade na região Nordeste do Brasil. Como não podia deixar de ser, ambos os escritores privilegiaram, em suas produções, o dialeto local, ou seja, reproduziram o que ouviam da população de seus locais de origem. Tanto Graciliano Ramos quanto José Lins do Rego descreveram com particular cuidado o calçado designado por alpargata, dedicando a ele várias passagens importantes, como se esse calçado fosse intrínseco às características dos personagens que o portavam. É o que confirmam esses excertos de Fogo Morto:

O mestre seleiro, sem chapéu, assim de camisa para fora das calças como estava, foi andando pela estrada. [...] Os pés inchados doíam nas pedras do caminho. A sua alpercata batia forte no silêncio da noite. [...] Marchava devagar. As suas alpercatas batiam alto no calcanhar. Estava só naquele mundo, sem uma pessoa, sem um ente vivo. (REGO, 2009, p. 112-113, 116)

$\mathrm{Na}$ citação, o narrador, em terceira pessoa, apresenta o personagem Mestre Zé Amaro, de profissão seleiro, referindo-se ao calçado que ele usa como alpercatas, uma variante lexical da norma padrão, apesar de o artesão não ter perfil de homem letrado no que diz respeito à escolaridade formal. Fica evidenciado, portanto, que a cada vez que Rego deixa falar, pela voz do narrador, o personagem Mestre Amaro, é por meio da forma culta da língua. Mestre Amaro usa e fabrica alpercatas. Em contrapartida, quando o narrador apresenta o personagem Negro Passarinho, fica expressa uma variante fonética popular, como na seguinte passagem: 
O negro Passarinho apareceu com os olhos vermelhos, para lhe falar: - Mestre Zé, estou com tenção de lhe encomendar um par de 'aparagata'. O senhor faz?

Não lhe deu ouvido. Continuou no seu refúgio, na sua gruta de pedra, com o escuro da noite, com o frio da noite no coração.

- Mestre Zé, insistiu o negro.

Aí acordou. Era como se tivesse visto pela primeira vez o negro, como uma criatura estranha que tivesse surgido para lhe falar.

- O que é que você quer, Passarinho?

- É um par de 'aparagata'. Daquela dos cangaceiros.

Não lhe disse nada e levantou-se para botar para dentro de casa os seus petrechos de trabalho. (REGO, 2009, p. 127).

Este último personagem, como o próprio nome indica, tem origem africana e, forçosamente, ancestrais escravos. Considerando-se o período em que se passa o romance, início do século XX, três ou quatro décadas após a abolição da escravatura, os afrodescendentes seguiam com um status muito semelhante àquele que tinham antes da alforria. Criado à margem da educação formal, Negro Passarinho fala diferente da norma culta da língua portuguesa: ele encomenda ao Mestre Amaro um par de 'aparagata', com a palavra escrita entre aspas. Note-se que o autor, na pessoa do narrador, demarca aí a diferença entre os dois personagens. O seleiro fabrica alpercatas, e Passarinho quer 'aparagata', uma variante fonética da forma padrão, como se pode conferir nas duas citações que se seguem.

Era domingo, mas trabalhava o seleiro. Alípio tinha encomendado meia dúzia de alpercatas. Era trabalho para o bando. Deixou tudo de lado para o serviço que fazia com toda a sua alma. [...] Quando voltou para a cozinha o mestre retornou à vida que o alimentava, aos homens que precisavam dos seus serviços. Agora não estava consertando os arreios de um velho doido, não estava fazendo sela para um camumbembe qualquer. Trabalhava para o grupo de Antônio Silvino. Cortava solas para cabras que já sabiam morrer no rifle, para gente que tinha sangue de macho. Não era um pobre seleiro de beira de estrada, era mais que um oficial de bagaceira de engenho. O capitão Antônio Silvino saberia de seu nome. [...] Que fossem para o inferno os grandes da terra. Para ele só havia uma grandeza no mundo, era a 
grandeza do homem que não temia o governo, do homem que enfrentava quatro estados, que dava dor de cabeça nos chefes de polícia, que matava soldados, que furava cercos, que tinha poder para adivinhar os perigos. A quicé chiava na sola branda. Faria alpercatas fortes para romper a terra dura das catingas, os espinheiros, as pedras, o barro quente. [...] Batia as brochas nas alpercatas com uma fúria de desespero. [...]

- E o capitão?

- Mestre, ele anda por longe. A última vez que peguei o bando foi lá em cima, no tabuleiro. Por sinal que o homem ficou satisfeito com o serviço. Os meninos gostaram das 'aparagatas'. (REGO, 2009, p.144-145, 173).

Mestre Zé Amaro, seja quando é trazido à cena pelo narrador, seja quando faz suas próprias elucubrações, utiliza a língua portuguesa culta. Já Negro Passarinho se exprime por intermédio de uma designação que reflete sua condição social, inferindo-se daí a perspectiva diastrática que o autor deixa transparecer no texto. Na pirâmide social, um seleiro, ainda que humilde, está num patamar mais elevado que um "negro", segundo as próprias palavras do autor. Por isso, o calçado que deseja Negro Passarinho é 'aparagata'. Rego, ao trazer a palavra entre aspas, faz questão de demonstrar que essa variante fonética não está inscrita na norma culta. Ilari (2003, p. 196) chama a atenção para esse dialeto, menos valorizado, mas muito comum entre os falantes:

O português sub-standard é a variedade mais usada, mas é tipicamente a língua das camadas mais pobres da população brasileira e, por isso, é objeto de uma forte discriminação que a escola teria a obrigação social de combater. Um bom começo para esse combate consiste em entender que se trata de uma língua que tem sua própria gramática, tão válida e tão eficaz quanto a da variedade standard.

A descrição das alpercatas também não deixa dúvidas: elas são confeccionadas em couro cru: "Cortava solas [...] A quicé chiava na sola branda" (REGO, 2009, p. 144-145). As alpercatas encomendadas pelo grupo do cangaceiro Antônio Silvino precisavam ser fortes o suficiente para permitir a movimentação na caatinga, fugir pelos caminhos de pedregulhos e espinhos. 
Observe-se que Mestre Amaro não trata os cangaceiros de Antônio Silvino como "bando", designação depreciativa, conduzindo, certamente, o leitor a pensar em marginais, em criminosos. O seleiro "trabalhava para o grupo de Antonio Silvino" (REGO, 2009, p. 144, grifo nosso). É um grupo, não um bando. Amaro está, portanto, revestido da causa que impelia Silvino a se bater contra os "grandes da terra [...] homem que enfrentava quatro estados, que dava dor de cabeça nos chefes de polícia, que matava soldados, que furava cercos [...]" (REGO, 2009, p. 145). Por isso, o seleiro "faria alpercatas fortes" (REGO, 2009, p. 145). Deduz-se, então, que o calçado é de couro, e não de lona. Nenhum tipo de tecido resistiria à vegetação da caatinga, às xerófitas que ali proliferam, somente o couro, que se constituía em matériaprima para alpercatas e também calças e casacos, tanto para homem como para mulher.

Em Vidas Secas, Graciliano Ramos (1969) opta por apenas uma variante lexical, a culta: alpercatas. O narrador, ao acompanhar a malfadada história do retirante Fabiano, só apresenta essa designação, da primeira à última página:

As manchas dos juazeiros tornaram a aparecer, Fabiano aligeirou o passo, esqueceu a fome, a canseira e os ferimentos. As alpercatas dele estavam gastas nos saltos, e a embira tinha-lhe aberto entre os dedos rachaduras muito dolorosas. Os calcanhares, duros como cascos, gretavam-se e sangravam. (RAMOS, 1969, p. 46).

Ramos, que dotou a cachorra Baleia, personagem de Vidas Secas, de sentimentos e características quase humanos, também deu tratamento especial às alpercatas. O que se retém da leitura é que o calçado parece ser uma extensão do corpo de Fabiano, e que sem as alpercatas ele não poderia franquear a paisagem adversa, seria impossível romper a secura do chão:

A areia fofa cansava-o, mas ali, na lama seca, as alpercatas dele faziam chape-chape, os badalos dos chocalhos que lhe pesavam no ombro, pendurados em correias, batiam surdos. [...] Chape-chape. As alpercatas batiam o chão rachado. O corpo do vaqueiro derreava-se, as pernas faziam dois arcos, os braços moviam-se desengonçados. Parecia um macaco. (RAMOS, 1969, p. 52, 54). 
"Chape-chape". A onomatopeia marca o andar arrastado e lamentoso de Fabiano. É a sina do vaqueiro que fala por meio das alpercatas. Elas sustentam o corpo extenuado do retirante, exprimem a fadiga daquele que a calça. Segundo Ferreira (2004), trata-se de vocábulo onomatopeico que designa "som produzido pelos passos de alguém quando anda em terreno lamacento". Para Aulete (s.d.), "chape" é o "ruído de uma pessoa andando sobre a lama". Fabiano anda sobre lama seca, sobre mosaicos rasgados de uma terra esturricada. Um passo, depois mais um passo, e Fabiano segue, levado pelas alpercatas gastas. O narrador não diz explicitamente que as alpercatas são de couro, mas tudo indica que um modelo em lona ou qualquer outro tipo de tecido não resistiria à paisagem. É o que se infere nesse ponto: “... e os pés deles esmoreciam, as alpercatas calavam-se na escuridão. Seria necessário largar tudo? As alpercatas chiavam de novo no caminho coberto de seixos." (RAMOS, 1969, p. 163).

O "caminho coberto de seixos", como descreve o narrador, não sugere outro tipo de calçado que não seja do tipo rudimentar, e esse calçado é a alpercata de couro, popular entre os sertanejos. Por isso mesmo, o narrador conduz o leitor rumo a uma evidência: o calçado não tem prestígio para adentrar em locais onde o protocolo exige certa formalidade. Isso se atesta nesse trecho da obra:

Para avistar a cabeça da mulher, Fabiano precisava estirar-se, voltar o rosto. E o colarinho furava-lhe o pescoço. E as botinas e o colarinho eram indispensáveis. Não poderia assistir à novena calçado em alpercatas, a camisa de algodão aberta, mostrando o peito cabeludo. Seria desrespeito. (RAMOS, 1969, p. 116).

Fabiano troca as alpercatas de todo dia por um par de botinas, mete-se em colarinho e fecha a camisa até o pescoço quando de um evento mais formal, como a novena citada. Mais uma vez aqui, a marca diastrática, mas na perspectiva das convenções sociais, e o sertanejo conhece os códigos: as alpercatas são para a lida, e botinas para as ocasiões especiais.

A acessibilidade ao calçado, ou seja, mesmo pessoas de baixo poder aquisitivo, como Fabiano, um retirante da seca que perdeu todos os bens, é evidenciada: não se trata de um produto caro, qualquer um pode adquirir alpercatas novas. É o que diz o texto: 
Agora Fabiano estava meio otimista. Endireitou o saco de comida, examinou o rosto carnudo e as pernas grossas da mulher. [...] Continuou a tagarelar, agitando a cabeça para afugentar uma nuvem que, vista de perto, escondia o patrão, o soldado amarelo e a cachorra Baleia. Os pés calosos, duros como cascos, metidos em alpercatas novas, caminhariam meses. (RAMOS, 1969, p. 163).

\section{Considerações Finais}

A análise das variantes lexicais para o calçado designado por alpargata teve como ponto de partida os dados do Atlas Lingüistico do Paraná-ALPR, de Aguilera (1994). À questão de número 276 do Questionário SemânticoLexical do ALPR, que tinha como semas: 'calçado antigo', 'de lona' e 'sola de corda trançada', os informantes registraram inúmeras variantes lexicais. Depois de examiná-las, concluímos que o calçado designado por alpargatas refere-se a um modelo patenteado pela São Paulo Alpargatas Company, colocado à venda com o nome de Alpargatas Roda. O nome da marca, metonimicamente, acabou se estendendo a todos os calçados com design semelhante.

Os registros lexicais do ALPR forneceram subsídios para delinear as alpargatas que os informantes tinham em mente: feitas em lona; com solado em corda ou emborrachado; fechadas, para os homens; e com tiras, para mulher. As alpargatas foram concebidas com finalidade puramente comercial: o trabalho no local da secagem do café, os conhecidos terreirões, que nada mais eram que um grande pátio cimentado onde se espalhavam os grãos do café. Durante o dia, enquanto os grãos de café secavam ao sol, era necessário revirá-los com um rastelo, e, para isso, os trabalhadores tinham que andar em cima dos grãos como se pisassem em ovos, caso contrário, o risco de esmagar os grãos era grande. Em resumo, a qualidade do café dependia diretamente da maneira como os trabalhadores se portassem ao andar em cima da camada de grãos. Até 1888, data da abolição da escravatura no Brasil, os escravos faziam o trabalho de pés nus, sem que seus senhores se preocupassem com o desconforto de andar horas em cima de grãos. Segundo Ribeiro (1996), com a abolição, e a consequente recusa de muitos ex-cativos em retomar o trabalho nos cafezais nas antigas condições, o Brasil passou a incentivar a vinda de imigrantes, com destaque para os italianos, com a conivência dos governantes dos países de onde eles partiam. Desempregados 
e em situação degradante em seus países de origem, poderiam fazer fortuna na América, o que nem sempre se configurou em realidade. Com a chegada dos imigrantes, a fábrica São Paulo Alpargatas Company, no começo do século XX, viu aí um filão econômico promissor. Lançou no mercado, portanto, um calçado voltado para os trabalhadores do setor cafeeiro. As alpargatas, pela leveza e pelo material (lona e corda) utilizado em sua fabricação, atenderam perfeitamente a demanda do setor, que, diga-se de passagem, fez a fortuna dos ditos Barões do Café, de São Paulo.

O contraponto proposto neste artigo, isto é, comparar as designações para um tipo de calçado rústico de lona, com solado em corda trançada, registradas por informantes no Paraná e no Nordeste do Brasil, teve ainda como corpus duas obras literárias: Vidas Secas (RAMOS, 1969) e Fogo Morto (REGO, 2009), visto que os dois autores destacam esse calçado em seus textos. Verificou-se em Vidas Secas a presença de apenas uma variante lexical: alpercatas. Ramos optou pela norma padrão da língua portuguesa. Em Fogo Morto estão registradas duas variantes fonéticas: alpercatas e aparagata. Esta última, uma variante fonética da forma culta, aparece sempre entre aspas, como a explicar que é uma unidade lexical popular, utilizada por pessoas de classe social menos favorecida.

As alpercatas, em Ramos (1969) e Rego (2009), têm um design totalmente distinto das que foram mencionadas pelos informantes do ALPR: são em couro, e não em tecido. Contudo, tal qual se passou no Sul do País, também no Nordeste as alpercatas foram criadas com finalidade prática: o calçado, fabricado em couro não tratado, facilitava ao sertanejo se embrenhar na caatinga, qualquer que fosse seu intento, seja procurar um bezerro desgarrado, seja se esconder da polícia, no caso específico dos cangaceiros. Foram esses, finalmente, que celebrizaram por lá as alpercatas. Constatamos ainda que o modelo popularizado por eles, para fazer frente à vegetação espinhenta, era comumente usado com uma perneira, também fabricada em couro. Alpercatas e perneiras, masculinas ou femininas, eram customizadas, com muitos rebites, fivelas e ilhoses, muito chamativas, como pode ser visto na foto de Inacinha, companheira de um cangaceiro dito Gato (MELLO, 2012). 


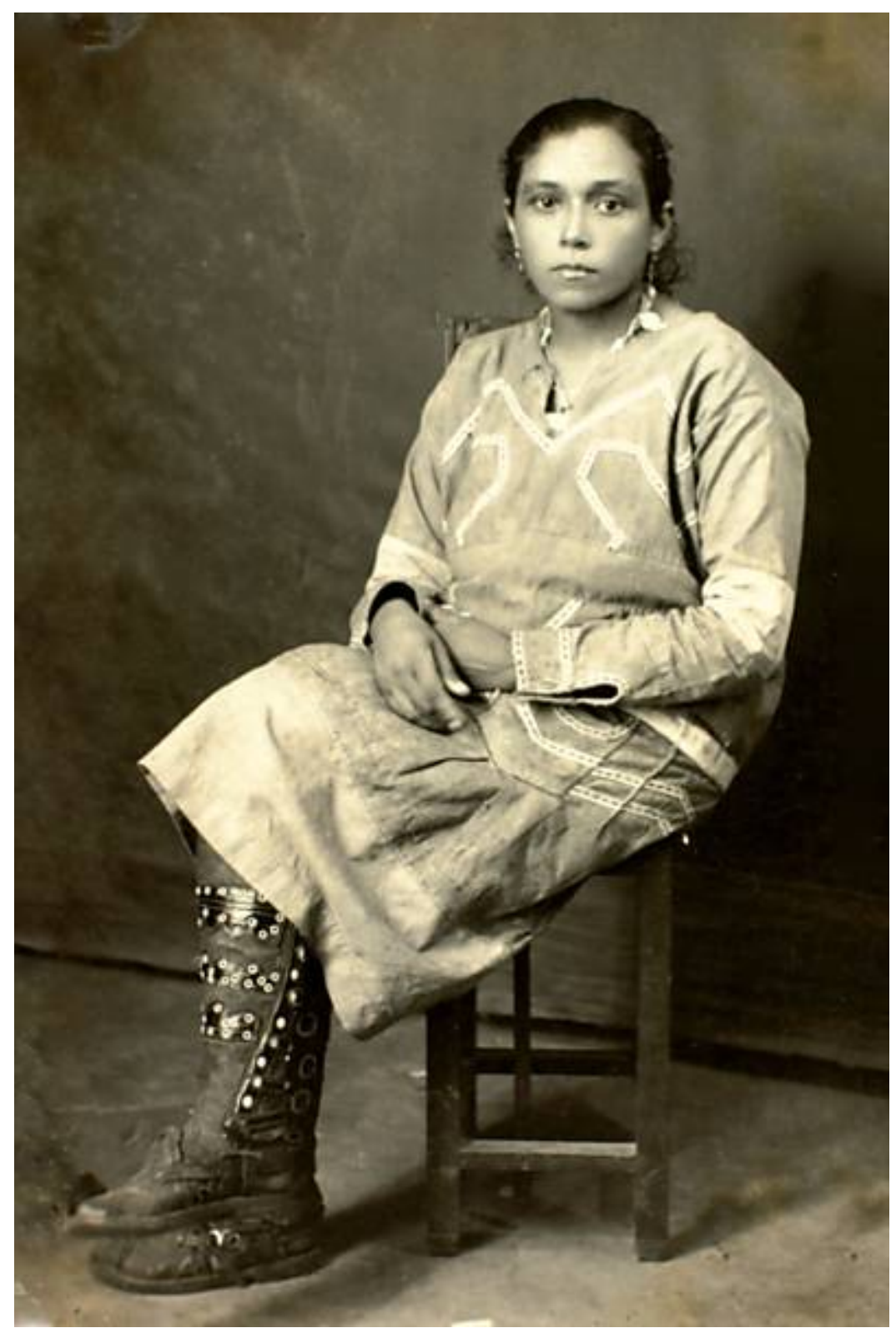

Fonte: Mello, 2012.

Figura 6 - Inacinha, em vestido de batalha, mostra como a perneira casava bem com a alpercata: Piranhas, Alagoas, 1936. 
A pesquisa revelou que, quanto à estética, as alpargatas nordestinas em nada se aproximam do modelo citado pelos informantes do ALPR. Quanto à concepção funcional, ambas apresentam semelhanças: foram criadas em função das necessidades da clientela local. Levando-se em consideração a data de surgimento, não há como afirmar qual dos modelos - em lona ou em couro - é mais antigo. Pode-se especular que, ao longo da história das civilizações, o homem tenha conseguido primeiro trabalhar o couro, já que, ao caçar animais para sustentar o grupo, viu utilidade nas peles e no couro, pois protegiam do frio e da chuva. Em função disso, pela lógica, rudimentos de calçados em pele ou couro parecem ter aparecido primeiro, pois, embora o cânhamo, citado por Anchieta, em carta de 1560, e outras plantas fibrosas, tais quais o junco e o sisal, por exemplo, fossem nativos em muitas partes do planeta, as técnicas de fiar surgiram mais tardiamente.

Podemos afirmar que, sob a perspectiva diatópica, as designações não apresentam disparidades: a designação alpercatas e sua variante fonética aparagatas, presentes nas obras literárias, também foram registradas no ALPR. Quanto à questão inicial que a pesquisa lançou, concluímos que, embora as variantes lexicais sejam semelhantes, o modelo de calçado a que se referem não é o mesmo no Paraná e no Nordeste.

Finalmente, a pesquisa desvelou o apreço que as alpargatas conquistaram junto à população, brasileira, tanto é que, constantemente, profissionais da moda revisitam o calçado e apresentam alpargatas estilizadas, confortáveis e sempre atuais. 


\section{Anexos}

Anexo A - Carta IV: Rede de pontos do ALPR

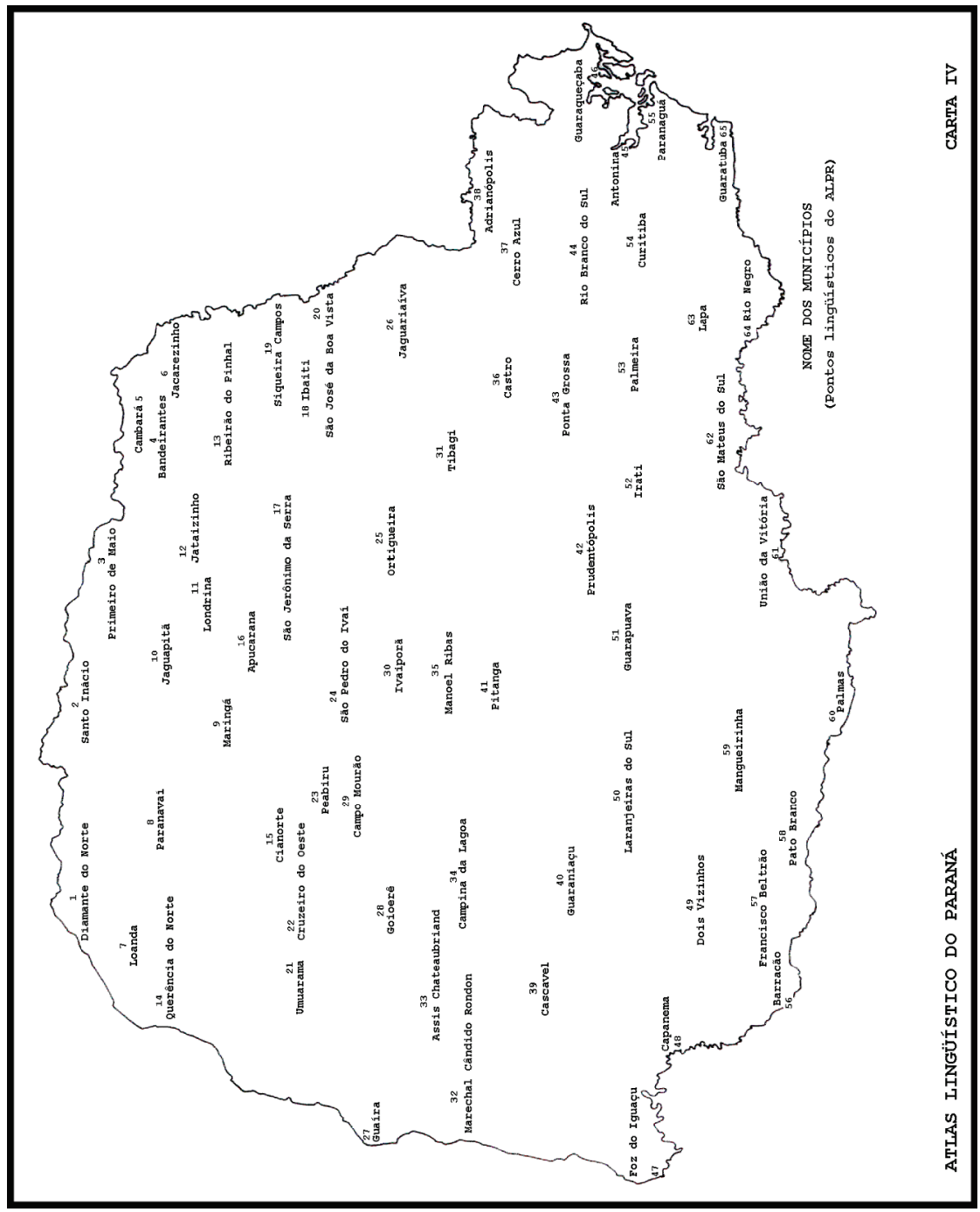

Fonte: Atlas Lingüístico do Paraná (AGUILERA, 1994). 
Anexo B - Carta III: Rede de pontos propostos por Nascentes em 1958

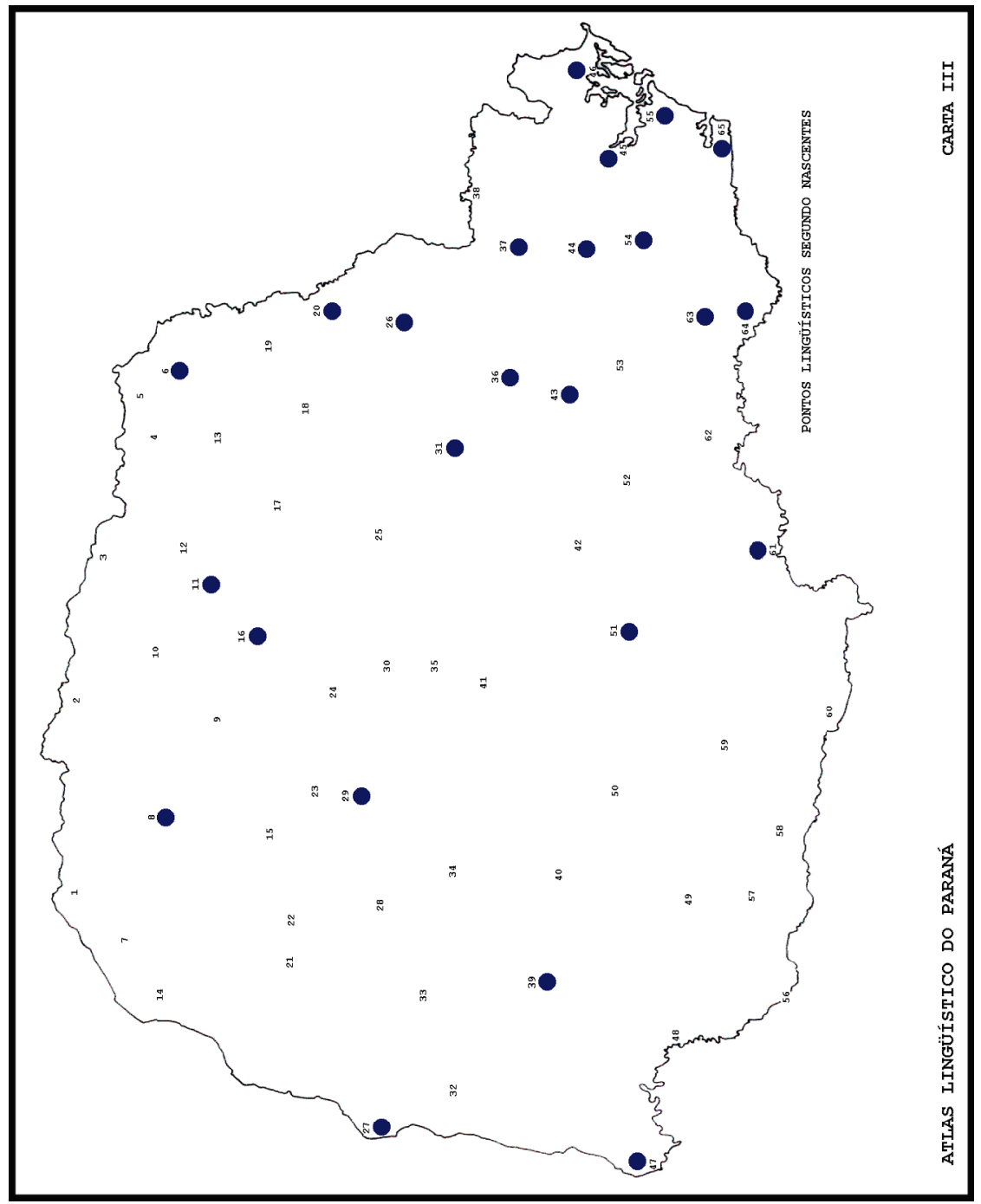

Fonte: Atlas Lingüístico do Paraná (AGUILERA, 1994). 


\section{Referências}

AGUILERA, V. de A. Atlas Linguístico do Paraná - ALPR. Curitiba: Imprensa Oficial do Estado, 1994.

ALENCAR, J. de. Til. Rio de Janeiro: José Olympio; MEC, 1977. Disponível em: <http://www.dominiopublico.gov.br/>. Acesso em: 20 abr. 2011.

ALPARGATAS. <www.alpargatas.com.br>. Acesso em: 20 abr. 2011. ANCHIETA, J. de. Cartas, informações, fragmentos históricos e sermões. Rio de Janeiro: Civilização Brasileira, 1933.

AULETE. iDicionário Aulete. Disponível em: <http://aulete.uol.com.br>. Acesso em: 03 out. 2012.

CARUSO, P. Questionário do Atlas Linguístico do Estado de São Paulo. Assis: Prefeitura do Município de Assis, 1984.

DEBRET, J.-B. Viagem pitoresca e histórica ao Brasil. São Paulo: Martins Brasília, 1975. Disponivel em: <pt.wikipedia.org/wiki/Jean-Baptiste_Debret>. Acesso em: 18 abr. 2011.

FERRAZ, H. Memórias revivem a SP da época da industrialização. Folha de S. Paulo, São Paulo, 19 jul. 2003. Disponivel em: <http:/ / www1.folha.uol.com.br/folha/ilustrada/ult90u35127.shtml>. Acesso em: 10 abr. 2011.

FERREIRA, A. B. de H. Novo dicionário da Lingua Portuguesa. 2. ed. rev. e aum. Rio de Janeiro: Nova Fronteira, 1986.

FERREIRA, A. B. de H. Novo dicionário Aurélio da Lingua Portuguesa. 3. ed. rev. e aum. Curitiba: Positivo, 2004.

FREYRE, G. Casa Grande e Senzala. Rio de Janeiro: Record, 1981.

ILARI, R. Introdução à semântica: brincando com a gramática. São Paulo: Contexto, 2001.

ILARI, R. Introdução ao estudo do léxico: brincando com as palavras. São Paulo: Contexto, 2003. 
LAROUSSE CULTURAL. Grande Enciclopédia. v. 2. São Paulo: Círculo do Livro, 1987a.

LAROUSSE CULTURAL. Grande Enciclopédia. v. 10. São Paulo: Círculo do Livro, 1987b.

LAROUSSE CULTURAL. Grande Enciclopédia. v. 24. São Paulo: Círculo do Livro, 1987c.

MELLO, F. P. de. A estética do cangaço. São Paulo: Escrituras, 2012.

MICHAELIS. Dicionário de Português Online. Disponível em: <http:// michaelis.uol.com.br>. Acesso em: 21 abr. 2011.

NASCENTES, A. Bases para a elaboração de um atlas lingüistico do Brasil. Rio de Janeiro: Casa de Rui Barbosa, 1958.

O RECLAME nos tempos idos. 13 out. 2011. Disponível em: <www.floradaserra.blogspot.com.br/2011/10/o-reclame-nos-temposidos.html>. Acesso em: 30 mar. 2012.

PARTIDO TRABALHISTA BRASILEIRO. In: Wikipédia. (s.d.).

Disponível em: <http://pt.wikipedia.org/wiki/

Partido_Trabalhista_Brasileiro>. Acesso em: 2 jul. 2013.

PROPAGANDAS das antigas. 14 out. 2009. Disponível em:

$<$ www.meusegundocaderno.blogspot.com/2009/10/propagandas-dasantigas.html>. Acesso em: 2 abr. 2011.

RAMOS, Graciliano. Vidas secas. 23. ed. São Paulo: Martins, 1969.

REGO, J. L. do. Fogo morto. 68. ed. Rio de Janeiro: José Olympio, 2009.

RIBEIRO, D. O povo brasileiro: a formação e o sentido do Brasil. São Paulo: Companhia das Letras, 1996.

SARAIVA, J. H. História concisa de Portugal. Lisboa: Saber Europa-América, 1983.

SILVA NETO, S. Guia para estudos dialetológicos. Belém: INPA, 1958. 